\title{
Beyond Nationaloper. For a Critique of Methodological Nationalism in Reading Nineteenth-Century Italian and German Opera
}

\author{
Axel Körner
}

\begin{abstract}
This article challenges traditional narratives that have tended to highlight the role of opera as a tool of political nationalism in nineteenth-century Europe. Instead, I will show how opera (both the form and the repertoire) served as a means of creating cultural and intellectual connections between peoples, and how it participated in the emergence of a European public. Claims that particular operas played a role in rousing nationalist sentiment are often methodologically unsound, due to the limitations of related sources of reception; or they are based on myths that were constructed long after these works' original production. Moreover, even works written or described at the time as explicitly 'national' operas often relied on musical techniques amalgamated from different national contexts, raising questions over their classification in terms of national culture. Instead, Italian opera in particular assumed a central role in building cultural bridges between nations. This was especially the case within the Habsburg monarchy, where opera was understood as a reference to Italy's humanist legacy, based on a long tradition of reading opera as the reinvention of Greek drama. After 1815 and throughout the 1820s, the triumph of Rossini's works on almost every stage in Europe shows how opera transcended barriers between peoples, states and nations. A mere 'national' reading of such works risks missing the point of why opera became a European art form of a truly global appeal.
\end{abstract}

Keywords: Nationalism, Opera, Italian history, German history, Habsburg Empire, Transnationalism

\section{The Distortions of Methodological Nationalism}

Historians who refer to music and opera in their research -- usually to add a cultural perspective to their explanation of social and political processes -- tend to apply national categories of analysis to classify composers and their works. In the case of nineteenth-century Europe, their aim is often to highlight the role of opera as a tool of political nationalism (Curtis 2008; 
Katalanić 2010; Riley and Smith, eds 2016; Sorba 2014; Ther 2011; Ther 2014). The idea that music stands in the first instance for a national understanding of culture has considerable social impact, especially among non-academic audiences, for instance through CD - or concert booklets, or popular radio and television programmes. What happens here, from a methodological point of view, is that history, as a construction of the mind, takes the vast territory of the musical past and reorganises it according to political or ideological preferences. In doing so, historians apply teleological principles that recognise in the nation state the only and inevitable outcome of a narrowly defined progression towards political modernity. As a consequence of this manipulation of the musical past into a prefabricated present, these histories fall victim to the same ideological distortions that affect other genres of historical writing as well, especially histories of Europe's so-called Age of Nationalism. In order to retain the tainted logic of their line of argument, the same historians discuss any polities that seemingly resisted the ideology of national states as ahistorical barriers on the road to political progress, directly affecting their evaluation of huge multinational territories such as the Habsburg monarchy, or the Russian or Ottoman Empires. The outcome of such histories is a past narrowly explained on the basis of methodological nationalism, marking not only how we see and describe states and the people that populate them, but also what these people produced in terms of their cultural artefacts. (For a critical reflection on such narratives see Körner 2017a. For a recent critique of the historiographical construction of Italians in transnational context see Codignola 2019.)

Music and opera provide us with telling examples of entangled and transnational histories that defy the logic of these historiographical ventures, especially when it comes to connections between German, Austrian and Italian musical life, or when considering the role of music in multinational imperial settings such as the Habsburg- or Russian Empires. For instance, Mozart's Italian operas, after the composer's death, came to play a major role in German cultural life when an Italian troupe, from its base in Prague, continued to carry his works across the border to the musical centres of Saxony, at a time when it was rather uncommon to play music by composers who were no longer alive (Woodfields 2012). Put simply, Germany got to know Mozart thanks to an Italian troupe based in the Kingdom of Bohemia. During those years, Mozart's operas also stayed in the programme of Milan's Teatro alla Scala, one of the Habsburgs' principal theatres at the time, where they left an important impact on the emergence of Italy's nineteenth-century operatic canon. The culture that emerged from such encounters is the product of thoroughly entangled social, political and cultural histories that resist any attempts at national categorization (Körner 2017b). To further highlight 
the role of transnational encounters for our understanding of nineteenth-century music we can add here the example of the early globalisation of Italian opera. It received an important boost when an Italian troupe, under its Prussian director, left Livorno in the 1820s to carry Rossini's operas to Latin America. Reflecting a Spanish imperial tradition, these works were soon produced in translation, by singers of a variety of national and indeed multinational backgrounds (Walton 2012). This transnational context determined the conditions of musical production and seriously undermines preconceived ideas of an original operatic italianità ${ }^{\mathrm{i}}$ As Jürgen Osterhammel has shown, a key aspect of nineteenth-century culture was the spread of ever more sophisticated theatre buildings to even the most remote parts of the globe (Osterhammel 2014), a process that went hand-in-hand with an increase in the global mobility of the repertoire, of impresari and of entire companies (Walter 2016; Toelle 2010; Walton 2012).

\section{Beyond operatic italianità}

As the example of Mozart's opera has shown, even at home in the Old World it is almost impossible to tell the story of opera within the narrow parameters of national historiographies. Rossini's career adds an even more striking example. His rapidly increasing popularity, first as a musician and then as a composer, took him from the Papal States to Habsburg Venice and Bourbon Naples, before introducing new operatic forms in Vienna, and then ending his active operatic career in Paris, forty years before his death. The product of this creative process can hardly be described as the essence of a national operatic form. A work like his Zelmira of 1822 would not have been acceptable to the audience at the San Carlo of Naples, where he was then still based. Rossini wrote the work specifically for his upcoming visit to Vienna, introducing a new kind of opera that reflected both the specificity of what one might want to call the "local conditions of musical production" as well the expectations of an audience that would be capable of appreciating a work that pushed the existing boundaries of operatic conventions (Körner 2018a; on Zelmira's reception in Italy see Nicolodi 2017: 27f.). In this case, the Italian tenor Giovanni David was the great voice behind the opera's success in Vienna, but what made his performance special was something that at the time Italian audiences would have found unusual. None other than the Austrian Chancellor Klemens von Metternich identified what was new behind David's part in Zelmira and the way he produced it: "David is the premier singer of his kind," he wrote, "a beautiful tenor voice, with such a depth and a height that one thinks he is either the epitome of manliness or the very opposite. He takes the high $\mathrm{C}$ with his chest 
voice as easily as he goes down to his chest's depth. This method is unparalleled; and his acting is most accomplished; in one word, he leaves nothing to be desired; and there are few things in this world that I am so confident to judge." ${ }^{\mathrm{ii}}$ As an experienced traveller south of the Alps, Metternich had long been familiar with Rossini's music and had heard several of his works in Naples and elsewhere. ${ }^{\mathrm{iii}} \mathrm{He}$ therefore commented on Zelmira with the assertiveness of a highly perceptive expert and identified exactly what was different about the kind of tenor voice Rossini had envisaged. Singing a high $\mathrm{C}$ with the chest voice challenged existing ideas about gender and musical representation, but also preconceived concepts of operatic italianità. The new heroic tenor was Rossini's way of responding to the disappearance of the castrati, who had previously covered these roles in the dramatic setup of an opera seria. Certain of his own judgement, Metternich disregarded the views of professional critics, who might have been disconcerted by such profound changes within the operatic repertoire. ${ }^{\text {iv }}$ For the same reasons he ignored the national stereotypes about Italians in parts of the German language press, used here to dismiss Rossini's work. In promoting Italian opera in Habsburg Europe, Metternich was certain to have the future on his side; and he was proved right by the success of his operatic politics (Jacobshagen 2018).

As an Italian singer, Giovanni David used the Viennese stages to challenge ideas of operatic italianità. Another influential voice behind Rossini's global success was not Italian, but Spanish: the tenor Manuel García, who in 1816 had created the role of Count Almaviva in Rossini's opera buffa Il Barbiere di Siviglia in Rome. García's daughters Maria Malibran and Pauline Viardot were French, but celebrated all over the world for their interpretations of the international repertoire. ${ }^{\mathrm{v}}$ The example of this famous family alone demonstrates the difficulty of tying the idea of operatic italianità to the national origin of a voice, a connection a long tradition of scholarship going back to Rousseau had tried to establish (Kolassa and Körner, eds 2018). Challenging the same logic, Italian opera did not need Mediterranean landscapes to be successful; and there is no evidence that Italians were in a better position to appreciate Italian opera than audiences North of the Alps. The Austrian capital performed more of Rossini's operas, and for much longer runs, than any Italian city during the composer's life time (Kantner 1994; Kantner and Jahn 1992; Jahn 2007; Vellutini 2015; Clark 2005). While all over the world Rossini's operas seemed to respond to the experience of a new semantics of historical time (Walton 2007), within the realms of the Habsburg monarchy they also played an important role in dynastic representation, on occasions such as imperial weddings, during diplomatic events or the domestic travels of the imperial family (Körner 2018a). For instance, for the international delegation represented at the Congress of the Holy Alliance in Laibach/Ljubljana in 1821, a 
production of Rossini's Edoardo e Cristina became a rare moment of distraction from the new wave of revolutionary turmoil affecting the continent. ${ }^{\mathrm{vi}}$ An imperial reception in Lemberg/Lwów/Lviv, in 1823, shows how such imperial politics of opera were used within multinational settings. The Galician production combined the first act of Rossini's Elisabetta (in German) with a rural idyll in Polish, so as to unite a cosmopolitan message (represented by an Italian opera sung in German) with a reference to the local elites' national sense of belonging. ${ }^{\text {vii }}$ Connecting these two works was meant to take account of the supranational principles underlying the Austrian idea of state. For the same reason, the Habsburgs' dynastic events were rarely celebrated with works of German origin, despite the fact that many German operas were included in the regular repertoire of most theatres, which in many parts of the monarchy still attracted predominantly German-speaking audiences. For instance, in 1833, the Moravian city of Olmütz/Olomouc, which was still closely associated with the musical legacy of the city's former cardinal Archduke Rudolph, chose Rossini's Tancredi to mark the Emperor's birthday (Kopecký and Křupková 2017: 199). This was hardly surprising as Rudolph, who had been Beethoven's most important pupil, had always shown a great interest in Rossini (Kagan 1988; Čermák 2000). The court theatre in Vienna marked the wedding between Emperor Franz Joseph and Elizabeth in 1854 with a version of Rossini's Il Viaggio a Reims, renamed Un viaggio a Vienna (Clark 2005: 100), while twelve years later, the opera performed in Turin in honour of crown-prince Umberto's wedding to princess Margherita, was Dinorah by the German Giacomo Meyerbeer (Tedesco 2008: 202; Körner 2016: 42 f).

Such choices in the imperial politics of opera make it difficult to retain the view that opera in nineteenth-century Europe, and in particular Italian opera, mainly served to deliver nationalist and anti-imperialist messages, which throughout the nineteenth century were viciously repressed by an imperial police state -- an argument still frequently made. For instance, Carlotta Sorba reads all historically themed Italian operas of the early nineteenth century as 'the mirror-image of contemporary Austrian domination' (Sorba 2014: 59. Similar Gavazzeni 2011: 60; Plazzi 2007: 54), despite the fact that the Habsburgs did more than any European court to promote these works, including the appointment of Gaetano Donizetti to the position of court composer in Vienna. Philip Gossett argued that the Austrian censors 'wrought havoc on Verdi's operas' (Gossett 2012: 277), regardless of the fact that censors elsewhere often took an even more interventionist approach to his works; and that the first operas to be staged in the Habsburgs' Italian provinces after the Revolution of 1848 were those of Giuseppe Verdi, including Nabucco. Verdi was soon to become Emperor Franz Joseph's preferred composer (Kreuzer 2010: 54; Körner 2018b). The example of Rossini's Guillaume Tell, based 
on a play by Friedrich Schiller, serves to illustrate the problems of such narrow readings of Italian opera as anti-Imperial manifestations. Although many commentators have tended to describe Tell as a narrative of Austrian oppression (Banti 2000: 45; Clark 2005: 117; Gavazzeni 2011: 75 f; Plazzi 2007: 54) the Habsburgs made the work a showpiece of their imperial splendour, regularly playing its overture for official occasions of the state or at the imperial court, including the sumptuous openings of the Spanish Riding School in Vienna (For a more nuanced reflection see Grempler 1996; Senici 2012). Frequently, extracts from Tell appeared as ballet music on the stages of the royal theatres; ${ }^{\text {viii }}$ and over the following decades the opera's popularity survived every political backlash on the Empire: the loss of the Italian territories in 1859 , the liberation of Venice in 1866, and the constitutional compromise with Hungary in 1867.

The opera composer most frequently performed in nineteenth-century Europe was not Giuseppe Verdi, and not Richard Wagner, but Giacomo Meyerbeer, the German-Jewish head of music at the court of Berlin and the principal representative of French grand opéra, an operatic genre that stands for huge dramatic scale and heavy historical tropes, but also for opera's urbanisation at a time when it had largely lost its connection with the European courts to represent the tastes and intellectual preoccupations of Europe's urban middle classes (Gerhard 1998; Hibberd 2009). The success of grand opéra was intrinsically linked to the extraordinary means of musical production on offer in Paris, then the world's capital of opera, but also to opera's globalisation, with the music that had emerged in Paris being emulated in most parts of the world. Within the Italian peninsula, Florence premiered many of Meyerbeer's operas, not as French or German works, but as expressions of its own European ambition (Della Seta 1998; Della Seta 2013: 158-177; Nicolodi 2000; Tedesco 2009). An important condition of Meyerbeer's success in the world was the fact that grand opéra spoke an idiom that was perceived as communicating across national boundaries (Körner 2017a; Döhring and Jacobshagen, eds 1998). It was on this basis that Giuseppe Mazzini thought of Meyerbeer's works (and not of Verdi's or Wagner's) as "music of the future", a music that through its combination of a transnational musical language pursued an ethical agenda that had the potential to unite humanity. As Mazzini wrote in a note to be added to the English version of his Philosophy of Music, Meyerbeer "moralised the Drama, making it an echo of the world and its eternal vital problem. He is not a votary of the l'Art pour l'Art music; he is the prophet of the music with a mission, the music standing immediately below Religion. [...] One would say that he was given to us as a symbol of the future union, a link between the two worlds, the harmonising of which will constitute the highest musical expression of the future." ${ }^{\text {ix }}$ These 
remarks suggest that for Mazzini, the great lover of music and opera, Meyerbeer rather than Rossini or Verdi was the composer capable of supporting his cosmopolitanism of nations (Recchia and Urbinati, eds 2009).

Recent studies on grand opéra in transnational contexts (Hesselager, ed. 2018; ProtanoBiggs, ed. 2017) seem to support Mazzini's reading of Meyerbeer: When the Prussian composer died in May 1864, the Ménestrel of Paris praised him as a master who had succeeded "in writing cosmopolitan art" (Zimmermann 1998: 321). It is this idea and its extraordinary role within nineteenth-century global culture that makes grand opéra a highly significant object of study for historians used to reduce the nineteenth-century to an age of nationalism. Rather than serving the ideas of national independence and ethnic identity, grand opéra offered its audiences narratives that made it difficult to play one national community against another, profoundly questioning the idea of opera as a tool of nationalism. Instead, as demonstrated by Meyerbeer's Le Prophète or Les Huguenots, these works seemed to reveal divisions within national communities, while also referring to ideals that spoke to humanity as a whole (Hibberd 2009; Fulcher 1987; Everist, ed. 2016).

\section{"National" opera?}

A lot of recent musicological research has raised critical questions over the use of "national opera' as an analytical category (Stollberg, Rentsch, Gerhard, eds 2017: 17-71, 247-516), research that is insufficiently taken into account by historians. For instance, during the $1820 \mathrm{~s}$, critics on both sides of the Alps discussed the extent to which Rossini was influenced by a German musical tradition, contrary to a musicological convention that has tended to use Rossini as an example to emphasise the antagonism between Italian and German musical styles (on this debate see Mathew and Walton, eds 2013). The composer's blending of different styles could count in his favour, as seen in French and Austrian responses to his operas, but on other occasions it was held against him, in Italy as well as in Germany (Jacobshagen 2015: 296; Walton 2013; Vellutini 2015: 154). Rossini's own approach to these debates was often one of indifference or of ironic distance, as documented by the above-mentioned Viaggio a Reims, where in the opera's final act he introduced a transnational musical parody based on material taken from different national anthems.

These examples of operatic politics of culture raise the question whether the idea of 'national' opera played any important role at all in the history of nineteenth-century music. In early-nineteenth-century Germany the idea of writing and producing 'national' German operas 
was often propagated by a relatively small group of pamphleteers, which rarely resonated with musicians or composers. Even the advocates of 'national' opera often did not know what might make such works 'German': the plot, its soundscapes, or simply some vaguely defined underlying ideological concepts. Moreover, audiences often showed very little interest in such works, preferring instead the international repertoire, which usually meant works of Italian or French origin (Nicklas 2017). As Natalia Nicklas has been able to show, among the betterknown works, written explicitly as "national operas," was Meyerbeer's Ein Feldlager in Schlesien (1845) about Frederick the Great; but it served as a reference to the Prussian more than to a German idea of nation. Heinrich Marschner's Kaiser Adolph von Nassau (1845) und Ferdinand Hiller's Konradin, der letzte Hohenstaufe (1847) failed to enthuse German audiences, despite the fact that these plots offered the opportunity of linking the history of the Holy Roman Empire to that of a future German nation state. Proponents of opera's national reawakening in Germany were critical of Gaspare Spontini's role as court composer in Berlin, because he was considered a foreigner, despite the fact that as early as 1829 he had written an opera based on German imperial history, his Agnes von Hohenstaufen. All of these works were short-lived and are today mostly forgotten. Goethe's grandson Walter Wolfgang von Goethe wrote König Enzio, which never reached the stage (Nicklas: 131). In trying to find a musical form to treat these historical topics, their composers often turned to French grand opéra. While this model allowed them to approach the dramaturgical complexity of a historical plot, the French form undermined the concept of a German national opera. As a consequence, many commentators at the time thought that history did not make for a good 'national' opera. German folktales were thought to constitute a viable alternative, especially after the success of Wagner's Tannhäuser (1845), but very few composers chose to take this path.

Attempts of creating Polish and Czech 'national operas', later in the century, often relied on compositional techniques associated with either Meyerbeer or Wagner, or a combination of both, rather than a stock of 'national' folk themes (Belina-Johnson and Muir, eds 2013; Ritter 2017; Rentsch 2017). Even in France, attempts to write national or regional opera often relied heavily on Wagnerism, questioning the essence of what constitutes a national opera (Stopes 2018). Moreover, even operas on explicitly 'national' themes such as the birth of the Czech nation, often had their origin outside the Czech lands, as in the case of Conradin Kreutzer's romantic opera Libussa, which the German composer wrote for Vienna. Carl Maria von Weber's Freischütz, set in the Bohemian borderlands, has often been taken as Germany's first 'national opera;' but under its new title Čarostřelec Max and Agathe became Liborýn and Lidunka, to celebrate the same work as a Czech 'national opera' (Gabrielová 2007: 93). All 
this complicates attempts to make opera the centre piece of arguments on the cultural construction of nationalism in nineteenth-century Europe.

Over the past few decades, much research on opera in Bohemia has focussed on tension between German and Czech music, ignoring the role of Meyerbeer and Wagner in the emergence of a Czech repertoire, but also the huge role played in the region by Italian opera (Karbusicky 2005; Gabrielová 2007; Kopecký and Křupková 2017). This legacy went back to the seventeenth century, when productions of Italian opera sought to respond to the Habsburgs' dynastic relations with families such as the Gonzaga or the Medici (Schindler 2000). At the time, it was understood as a direct reference to the European Renaissance and Italy's humanist tradition, which conceived of opera as the reinvention of Greek classical drama (Cohen 2017: 6-52). On this basis productions of Italian opera extended to many of the Empire's regional capitals, provincial cities and theatres in numerous aristocratic palaces, where Italian opera was understood as a cosmopolitan idiom that spoke to the Empire's many peoples, reflecting the political ideas that informed the Habsburgs' multinational concept of state. As a consequence, in Habsburg Europe Italian opera always counted for more than a national tradition of one of the Empire's many nationalities.

In the context of this debate over what constitutes a 'national' opera, there probably is little to add to the controversies over Verdi's alleged role as 'bard of the Risorgimento' (Parker 1997; Parker 2012; Della Seta 2017; Körner 2017e), if not to point out that many of these myths are also enshrined in methodological nationalism and teleological views of history. The fact that around 1848 the composer started to identify with Italy's national movement, and that the country was subsequently unified, made it possible to present Verdi as 'national composer' to support the country's troubled process of inner nation building. There is no question that Verdi himself contributed to this myth by styling his own autobiography accordingly. Early biographers and representatives of Italy's national movement, supported by the press and subsequent generations of historians, contributed to this idea by re-reading the composer's earlier works in a 'national' key, including most famously his Nabucco of 1842. While such ideologically driven decisions might not seem surprising for nineteenth-century commentators, many of whom were themselves directly involved in the process of Italy's cultural nation building, today's historians and opera scholars should pay more attention to the critical analysis of their sources of reception, as well as to the underlying teleological and idealist conditions of nationalist historiography (Körner 2009).

Beyond this debate on the role of Verdi's operas in Italy's national movement, what is perhaps more relevant to a critical reflection on the concept of 'national opera' is the extent to 
which Italian opera, as well as opera in Italy, were both the products of intense transnational exchanges. For much of the eighteenth and nineteenth centuries composers of German and Austrian origin enjoyed immense success on the Italian stages, including Johann Christian Bach, Johann Adalbert Gyrowetz, Adolf Hasse, the young Meyerbeer, Joseph Weigl and Peter von Winter. Among them was also Johann Simon Mayr, who wrote over seventy works for all the major Italian theatres and who counted Donizetti among his students (Gatti 1964: 70 f). During Verdi's early years, the works of the Prussian court composer and founder of the Vienna Philharmonic Otto Nicolai were hugely popular in Italy (Kaufman 1990: 111-114). Many of these composers wrote for the Italian market of opera seria, but they did so on the basis of their acquaintance with a wider European musical tradition and of their own upbringing on German counterpoint. From today's perspective we might not necessarily see most of these composers as being central to the operatic canon, but they left a huge impact on the ways Italy's operatic life evolved during the nineteenth century. Stanislao Mattei, one of Italy's most influential teachers of composition, was known for his love of Mozart and Haydn, the two composers to whom Rossini was most frequently compared, especially by Stendhal (Panzacchi 1895: 116 f). Because during his early years in Lugo Rossini learned from a German maestro, he was later charged with having "adulterated the pure fount of Italian melody by bringing in far too much noisy German harmony” (Rosselli, J. 1991: 52; see also Gatti 1964: 61-112).

\section{Transnationalising Verdi's Genoa}

We easily think about Giuseppe Verdi as a quintessentially Italian composer, an italianissimo, with deep roots in the countryside between Piacenza and Parma (Gerhard 2013). However, this carefully crafted image, to which Verdi consciously contributed, contrasts with the many international influences on the composer's own style, as well as with his extensive travel that formed the basis of his work for foreign opera houses. Throughout the $1850 \mathrm{~s}$ and $-60 \mathrm{~s}$, the years leading up to Italy's political unification, Verdi worked closely with theatres in Paris. Among his many acquaintances in Paris was Giuseppe Montanelli, the federalist political theorist and leader of the Tuscan revolution of 1848, who assisted him with completing Francesco Maria Piave's libretto for Simon Boccanegra (1857). Set in fourteenth-century Genoa and steeped in references to local political traditions, there are at least six important passages of the opera that Montanelli drafted for Verdi and which reflect his political ideas (Walker 1960; Springer 2018; Budden 1992: 247). Montanelli's role in completing the libretto could easily be read as another sign of the composer's involvement with Risorgimento politics, 
but a careful analysis of the literary sources also illustrates how transnational entanglements contributed to the nation's literary and operatic culture. Montanelli's take on Piave's original libretto closely reflects his admiration for Friedrich Schiller, and in particular his familiarity with Schiller's depiction of Genoa's political life in Die Verschwörung des Fiesko zu Genua. Montanelli used Schiller's Fiesko to introduce his own ideas of Italy's local political culture into the plot of Simon Boccanegra. These ideas were based on a federal and republican past that according to his own view should never be superseded by a monarchical and unitary system foreign to the country's political tradition (Körner 2017d: 138-146).

Montanelli and Verdi were exposed to Schiller not only through Alessandro Manzoni's interest in the German poet and Giovanni Gherardini's translation of Schlegel's lectures on German literature (Kostka 1997; Del Vivo ed 2014: 130; Luseroni 1996: 45 f, 104; Rosselli, N. 1946: 101), but also through the prominent role Schiller played in French literary debates, in particular in Germaine de Staël's writings (Ragusa 1972: 296). ${ }^{\mathrm{x}}$ In addition to Die Räuber and Kabale und Liebe, both set to music by Verdi (I masnadieri, 1847, and Luisa Miller, 1849), Fiesko had been one of Schiller's first plays to be staged in Italy: first in 1806, followed by several more productions after 1815 and in 1847-1848. Translations of the play had circulated in Italy since 1819 (Unfer Lukoschik 2004: 253) and Verdi's library also contained an undated German edition of the work. In 1853, a few years before Verdi started work on Simon Boccanegra, Verdi's former friend and collaborator Andrea Maffei published another translation of the play, a work both Verdi and Montanelli probably knew. ${ }^{x i}$ As Anselm Gerhard has recently been able to establish, Verdi himself saw Schiller's play in Cologne shortly before he completed the revised version of Simon Boccanegra (Gerhard 2016). The example shows how an Italian plot, and a closely related debate on Italy's political culture, could be the outcome of a complex transnational web of intertextual references.

Although Verdi's collaboration with Montanelli took place in Paris, Simon Boccanegra was first produced at La Fenice in Venice, then still under Habsburg rule, where also $\mathrm{La}$ traviata had been premiered with direct support of the Habsburg government (Körner 2018b). Despite the great appreciation his Italian works enjoyed under the Habsburgs, Verdi was also keen to write French operas to be produced in Paris. After the French adaptation of his Macbeth, first staged in 1865, Verdi agreed to write again an opera based on Schiller, a French version of Don Carlos. As did so many of his operas, it became a truly cosmopolitan work: based on a German play about sixteenth-century Spain, featuring a Dutch revolt; composed on a French libretto for the Opéra in Paris; written not in the Italian tradition, but in the style of a French grand opéra, a genre widely associated with the recently deceased Prussian-Jewish 
composer Giacomo Meyerbeer. The first performance of Don Carlos in 1867 involved a cast of singers and dancers from all over Europe, before it crossed the Atlantic to be performed all over the world. In its musical language commentators have detected German, French, as well as Italian elements (Döhring 2013). Similar to his earlier American opera Un ballo in maschera (Körner 2017d: 163-198), Verdi's Don Carlos combines the representation of private and political passions in a cosmopolitan idiom that touches sentiments regardless of nationality.

\section{Conclusions}

These examples demonstrate the need to free our writing about nineteenth-century opera from the straight-jacket of national teleologies. Explaining historical developments as a function of its end will always result in distortions of the semantics of historical time and deprive the past of characteristics that were key to their historical significance. In Quentin Skinner's words, our task is ,to stand back from our own assumptions and systems of beliefs, and thereby to situate ourselves in relation to other and very different forms of life." (Skinner 2002: 125) We write history not to understand the present but to better understand the past. It is this past, freed from teleological ideology and constantly rewritten, that shapes our present. Critically assessing the sources for the production and reception of opera has the potential of making a major contribution to breaking with idealist conceptions of the nation state and will provide us with a more colourful idea of operatic life than those stained narratives that have manipulated the history of opera into something it never was.

\section{References}

Banti, A.M. 2000: La nazione del Risorgimento. Parentela, santità e onore alle origini dell'Italia unita. Turin: Einaudi.

Belina-Johnson, A. and Muir, S. eds 2013: Wagner in Russia, Poland, and the Czech Lands. Farnham: Ashgate.

Budden, J. 1992: The Operas of Verdi. Vol. 2: From Il trovatore to La forza del destino. Oxford: Clarendon, 1992

Bůžek, V. and Král, P. eds 2000: Slavnosti a zábavy na dvorech a v rezidenčních městech raného novověku. České Budějovice: Historický ústav Jihočeské university. 
Čermák, M. 2000: “Světské slavnosti raného novověku v Královské Olomouci”, in: Bůžek and Král, eds 2000: 399-408.

Clark, M. L. 2005: The Performances and Reception of Rossini's Operas in Vienna, 18221825. PhD dissertation, University of North Carolina, Chapel Hill.

Codignola, L. 2019: Blurred Nationalities across the North Atlantic. Traders, Priests, and their Kin travelling between North America and the Italian Peninsula, 1763-1846, Toronto, University of Toronto Press.

Cohen, M. 2017: The Politics of Opera. A History from Monteverdi to Mozart, Princeton: Princeton University Press.

Curtis, B. 2008: Music makes the Nation. Nationalist Composers and Nation Building in Nineteenth-Century Europe. Amherst, NY: Cambria.

Del Vivo, C. ed. 2014: In esilio e sulla scena. Lettere di Lauretta Cipriani Parra e Adelaide Ristori. Florence: Firenze University Press.

Della Seta, F. 1998: "Un aspetto della ricezione di Meyerbeer in Italia: Le traduzioni dei 'grands opéras"”, in: Döhring and Jacobshagen eds, 1998: 309-51.

Della Seta, F. 2013: Not without Madness. Perspectives on Opera, Chicago, University of Chicago Press.

Della Seta, F. 2017: “Opera e Risorgimento: si può dire ancora qualcosa?”, in:

Verdiperspektiven 2, 81-106.

Döhring, S. 2013: "Don Carlos”, in: Gerhard and Schweikert, eds 2013: 504-517.

Döhring, S. and Jacobshagen, A., eds 1998: Meyerbeer und das europäische Musiktheater. Laaber: Laaber.

Everist, M., ed. 2016: Meyerbeer and Grand Opéra from the July Monarchy to the Present. Turnhout: Brepols.

Figes, O. 2019: The Europeans. Three lives and the making of cosmopolitan culture. London: Allen Lane.

Fulcher, J. 1987: The Nations Image: French Grand Opera as Politics and Politicized Art. Cambridge: Cambridge University Press.

Gabrielová, J. 2007: “Carl Maria von Webers Freischütz in Prag”, in: Jörn Peter Hieckel and Elvira Werner, eds, Musikkulturelle Wechselbeziehungen zwischen Böhmen und Sachsen. Saarbrücken: Pfau, 91-98.

Gatti, C. 1964: Il Teatro alla Scala nella storia e nell'arte (1778-1963). Milan: Ricordi. 
Gavazzeni, G. 2011: Il melodramma ha fatto l'unità d'Italia, in: Giovanni Gavazzeni, Armando Torno, Carlo Vitali, eds, O mia patria. Storia musicale del Risorgimento, tra inni, eroi e melodrammi, Milan: Dalai, 51-183.

Gerhard, A. 1998: The Urbanization of Opera. Music Theater in Paris in the Nineteenth Century. Chicago and London: University of Chicago Press.

Gerhard, A. 2013: "Verdi-Bilder", in: Gerhard and Schweikert, eds 2013: 2-27

Gerhard, A. 2016: "Verdi, Hiller und Schiller in Köln - Ein unbeachtetes Albumblatt und die Frage möglicher Beziehungen zwischen Die Verschwörung des Fiesko zu Genua und Simon Boccanegra", Verdiperspektiven 1, 65-91.

Gerhard A. and Schweikert, U. eds 2013: Verdi Handbuch. (2. Auflage). Stuttgart/Weimar: Metzler/Bärenreiter.

Gossett, P. 2012: "Giuseppe Verdi and the Italian Risorgimento", Proceedings of the American Philosophical Society 156/3 (September), 271-282.

Grempler, M. 1996: Rossini e la patria. Studien zu Leben und Werk Gioacchino Rossinis vor dem Hintergrund des Risorgimento. Kassel: Bosse.

Hesselager, J., ed., 2018: Grand Opera Outside Paris. Opera on the Move in NineteenthCentury Europe. London: Routledge.

Hibberd, S. 2009: French Grand Opera and the Historical Imagination. Cambridge: Cambridge University Press.

Jacobshagen, J. 2015: Gioachino Rossini und seine Zeit. Laaber: Laaber-Verlag. Jacobshagen, A. 2018: "Rossini and his German Critics", in: Narici, Sala, Senici, Walton, eds, 2018: 381-411.

Jahn, M. 2007: Die Wiener Hofoper von 1810 bis 1836. Das Kärntnerthortheater als Hofoper. Wien: Apfel.

Susan Kagan, S. 1988: Archduke Rudolph, Beethoven's Patron, Pupil, and Friend, Stuyvesant: Pendragon Press.

Kantner, L. 1994: "Rossini nello specchio della cultura musicale dell'impero asburgico", in: La recezione di Rossini ieri e oggi. Convegno organizzato con la collaborazione della Accademia Nazionale di Santa Cecilia, Rome: Accademia nazionale dei Lincei, 215-222. Kantner, L. and Jahn, M. 1992: "Il Viaggio a Vienna”, in: Mauro Bucarelli, ed., Rossini 1792-1992. Mostra storico-documentaria. Perugia: Electa, 197-204.

Karbusicky, V. 2005: Geschichte des böhmischen Musiktheaters. Hamburg: von Bockel. Katalinić 2010: "Der Topos der Nation auf der Musikbühne am Anfang der Kroatischen Nationaloper in Zagreb”, in: Müller, Ther, Toelle, Zur Nieden, eds 2010: 219-243. 
Kaufman, Thomas G. 1990: Verdi and his major contemporaries. A selected chronology of performances and casts. New York: Garland.

Kolassa, A. and Körner, A. eds 2018: Opera in Transnational Context: Reading Rousseau's "Essay on the Origin of Languages", http://passionatepolitics.eu/opera-in-transnationalcontext-rousseau/

Kopecký, J. and Křupková, L. 2017: Das Olmützer Stadttheater und seine Oper. Regensburg: ConBrio.

Körner, A. 2009: “The Risorgimento's literary canon and the aesthetics of reception: some methodological considerations", Nations and Nationalism, 15/3 (July), 410-418.

Körner, A. 2016: "Heirs and their Wives. Setting the scene for Umbertian Italy", in: Heidi Mehrkens and Frank Lorenz Müller (eds), Sons and Heirs. Succession and Political Culture in 19th-Century Europe. New York / London: Palgrave Macmillan, 38-52.

Körner, A. 2017a: "Transnational History: Identities, Structures, States”, in: Barbara HaiderWilson, William D. Godsey, Wolfgang Mueller, eds, International History in Theory and Praxis, Vienna, Verlag der Österreichischen Akademie der Wissenschaften, 265-290.

Körner, A. 2017b: "Dalla storia transnazionale all'opera transnazionale. Per una critica delle categorie nazionali”, Saggiatore Musicale XXIV (2017/1), 81-98.

Körner, A. 2017c: "From Hindustan to Brabant: Meyerbeer's Africana and Municipal Cosmopolitanism in Post-Unification Italy”, Cambridge Opera Journal 29/1 (March), 74-93. Körner, A. 2017d: America in Italy. The United States in the Political Thought and Imagination of the Risorgimento, 1763-1865. Princeton: Princeton University Press. Körner 2017e: “Oper, Politik und nationale Bewegung. Mythen um das Werk Giuseppe Verdis“, in: Hannes Siegrist und Thomas Höpel, eds, Kunst, Politik und Gesellschaft in Europa seit dem 19. Jahrhundert. Stuttgart: Franz Steiner, 99-110.

Körner, A. 2018a: "Culture for a Cosmopolitan Empire: Rossini between Vienna and the Lands of the Bohemian Crown”, in: Narici, Sala, Senici, Walton, eds 2018: 357-380.

Körner, A. 2018b: “Che il pubblico non venga defraudato degli spettacoli ad esso promessi. The Venetian premiere of La traviata and Austria's imperial administration in 1853", Verdiperspektiven 3, 93-109.

Kostka, E. 1997: Schiller in Italy. Schiller's Reception in Italy: $19^{\text {th }}$ and $20^{\text {th }}$ Centuries. New York: Peter Lang.

Kreuzer, G. 2010: Verdi and the Germans. From Unification to the Third Reich. Cambridge: Cambridge University Press. 
Luseroni, G. 1996: Giuseppe Montanelli e il Risorgimento. La formazione e l’impegno civile e politico prima del'48. Milan: Franco Angeli.

Mathew, N. and Walton, B., eds 2013: The Invention of Beethoven and Rossini.

Historiography, Analysis, Criticism. Cambridge: Cambridge University Press.

Müller, S. O., Ther, P., Toelle, J., Zur Nieden, G., eds 2010: Die Oper im Wandel der

Gesellschaft. Kulturtransfers und Netzwerke des Musiktheaters in Europa. Vienna: Böhlau.

Narici, I., Sala, E., Senici, E., Walton, B., eds 2018: Gioachino Rossini 1868-2018: La

musica e il mondo. Pesaro: Fondazione Rossini.

Nicolodi, F. 2000: “Les grands opéras de Meyerbeer en Italie (1840-1890)”, in: Hervé Lacombe, ed., L'opéra en France et en Italie (1791-1925): Une scène privilégiée d'échanges littéraires et musicaux. Paris: Société Française de Musicologie, 87-115.

Nicolodi, F. 2017: L'attività dei teatri fiorentini sotto Ferdinando III (1814-1824) nel giudizio della Gazzetta di Firenze, in: Adriana Guarnieri Corazzol, Ignazio Macchiarella, Fiamma Nicolodi, eds, Musiche e musicisti nell'Italia dell'Ottocento attraverso i quotidiani. Ariccia: Aracne, 23-54.

Nicklas, N. 2017: Nationalisierung der deutschen Oper im späten Vormärz 1840-1848.

Stuttgart: Franz Steiner.

Osterhammel, J. 2014: The Transformation of the World: A Global History of the Nineteenth Century. Princeton: Princeton University Press.

Panzacchi, E. 1895: Nel Mondo della musica. Florence: Sansoni.

Parker, R. 1997: 'Arpa d'or dei fatidici vati': The Verdian Patriotic Chorus in the 1840s.

Parma: Istituto di studi verdiani.

Parker, R. 2012: "Verdi politico: a wounded cliché regroups", Journal of Modern Italian Studies, (Special issue: Opera and Nation in nineteenth-century Italy), 17/4 (September), 427-436

Parker, R. and Rutherford, S. eds 2019: London Voices 1820-1840. Vocal Performers, Practices, Histories. Chicago and London: University of Chicago Press.

Plazzi, C. 2007: Nemico della patria! Migranti e stranieri nel melodramma italiano da Rossini a Turandot. Acireale: Bonanno, 2007.

Protano-Biggs, L., ed. 2017: Nineteenth-Century Grand Opéra on the Move. Special issue: Cambridge Opera Journal, 29/1 (March).

Ragusa, O. 1972: “Italy, Romantico - Romanticismo”, in: Hans Eichner, ed., 'Romantic' and its Cognates: The European History of a Word. Manchester: Manchester University Press, 293-340. 
Recchia S. and Urbinati, N. eds 2009: A Cosmopolitanism of Nations. Giuseppe Mazzini's Writings on Democracy, Nation Building, and International Relations. Princeton: Princeton University Press.

Rentsch, I. 2017: “"Keine Spur von Lohengrin'. Die 'verspätete' Wagner-Rezeption in Prag”, in: Stollberg, Rentsch, Gerhard, eds 2017: 291-306.

Riley, M. and Smith, A. D., eds 2016: Nation and Classical Music. From Handel to Copland, Woodbridge: Boydell.

Ritter, R. 2017: "Nationale Mission und panslawistisches Sendungsbewußtsein in der polnischen Musik des 19. Jahrhunderts", in: Stollberg, Rentsch, Gerhard, eds 2017: 335-359. Rosselli, J. 1991: Music and musicians in Nineteenth-Century Italy. London: Batsford. Rosselli, N. 1946: Saggi sul Risorgimento e altri scritti. Turin: Einaudi.

Rutherford, S. 2006: The Prima Donna and Opera, 1815-1930. Cambridge: Cambridge University Press.

Schindler, Otto G. 2000: “'Die wälischen comedianten sein ja guet'... Die Anfänge des italienischen Theaters am Habsburgerhof’, in: Bůžek and Král eds 2000: 107-136.

Senici, E. 2012: “'An atrocious indifference': Rossini’s operas and the politics of musical representation in early-nineteenth-century Italy”, Journal of Modern Italian Studies 17/4 (September), 414-426.

Skinner, Q. 2002: Visions of Politics, vol.1: Regarding Method. Cambridge: Cambridge University Press.

Sorba, C. 2014: "Between cosmopolitanism and nationhood: Italian opera in early nineteenth century”, Journal of Modern Italian Studies, 19/1, 53-67.

Späth, J. 2012: Revolution in Europa 1820-23. Verfassung und Verfassungskultur in den Königreichen Spanien, beider Sizilien und Sardinien-Piemont, Köln: SH.

Späth, J. 2019: “Turning Constitutional History Upside Down: The 1820s Revolutions in the Mediterranean”, in: Tessa Hauswedell, Axel Körner, Ulrich Tiedau, eds, Remapping Centre and Periphery: Asymmetrical Encounters in European and Global Context, London: UCL Press, 111-134.

Springer, C. 2008: Giuseppe Verdi: "Simon Boccanegra”. Dokumente-Materialien - Texte zur Entstehung und Rezeption der beiden Fassungen. Wien: Praesens, 241-252.

Stollberg, A., Rentsch, I., Gerhard, A., eds 2017: Gefühlskraftwerke für Patrioten? Wagner und das Musiktheater zwischen Nationalismus und Globalisierung. Würzburg: Königshausen \& Neumann. 
Stopes, H. 2018: "Lydéric, sauveur de Flandres: décentralisation théatrale and the local politics of the opera in Lille, 1881-1896", French History, 32/3, 387-407.

Tedesco, A. 2008: “"Queste opere eminentemente sinfoniche e spettacolose”: Giacomo Meyerbeer's Influence on Italian Opera Orchestras', in: Niels Martin Jensen and Franco Piperno (eds), The Opera Orchestra in 18th-and 19th-Century Europe, vol. 2: The Orchestra in the Theatre - Composers, Works, and Performance, Berlin: Berliner Wissenschaftsverlag, $185-227$.

Tedesco, A. 2009: “'Le Prophète' in Italy”, in: Matthias Brzoska, Andreas Jacob and Nicole K. Strohmann, eds, Giacomo Meyerbeer: Le Prophète. Edition-Konzeption-Rezeption, Hildesheim: Olms, 565-602

Ther, P. 2011: "The Genre of National in a European Comparative Perspective", in: Fulcher, J. ed., 2011: 182-208.

Ther, P. 2014: Center Stage. Operatic Culture and Nation Building in Nineteenth-Century Europe, West Lafayette, IN: Purdue University Press.

Toelle, J. 2010: “Der Duft der großen weiten Welt. Ideen zum weltweiten Siegeszug der italienischen Oper im 19. Jahrhundert,” in: Müller, Ther, Toelle, Zur Nieden, eds 2010: 251261.

Unfer Lukoschik, R. 2004: Friedrich Schiller in Italien (1785-1861). Eine

quellengeschichtliche Studie. Berlin: Duncker \& Humblot.

Vellutini, C. 2015: Cultural Engineering: Italian Opera in Vienna, 1816-1848. PhD Thesis University of Chicago.

Walker, F. 1960: "Verdi, Giuseppe Montanelli and the Libretto of Simon Boccanegra", Bollettino dell'Istituto di Studi Verdiani 1/3, 1373-1390.

Walter, M. 2016: Oper. Geschichte einer Institution. Stuttgart: J. B. Metzler and Kassel: Bärenreiter.

Walton, B. 2007: Rossini in Restoration Paris: The Sound of Modern Life. Cambridge, Cambridge University Press.

Walton, B. 2012: "Operatic fantasies in Latin America”, Journal of Modern Italian Studies 17/4 (September), 460-471.

Walton, B. 2013: “"More German than Beethoven': Rossini’s Zelmira and Italian style”, in: Mathew and Walton, eds, 2013: 159-177.

Woodfield, I. 2012: Performing Operas for Mozart: Impresarios, Singers and Troupes.

Cambridge: Cambridge University Press. 


\section{Zimmermann, R. 1998: Giacomo Meyerbeer. Eine Biografie nach Dokumenten. Berlin:}

Reclam.

\footnotetext{
${ }^{\text {i }}$ The critical analysis of the relationship between Italian opera and national character in transnational and global perspective was the topic of an international research network, financed over a period of a three years by the Leverhulme Trust and hosted by the UCL Centre for Transnational History: "Reimagining Italianità. Opera and musical culture in transnational perspective". See: https://www.ucl.ac.uk/centre-transnational-history/researchand-publications/re-imagining-ita

ii Clemens Wenzel Lothar Fürst von Metternich, "Tagebuch 8. April 1822“, in: Aus Metternich's nachgelassenen Papieren, Richard Fürst von Metternich-Winneburg, ed., Part II, Volume 1, Vienna: Braunmüller, 1881, 508-509 iii Metternich heard eight of Rossini's Neapolitan operas at the San Carlo in 1819. See Metternich to his wife, 3 May 1819, in: Clemens Wenzel Lothar Fürst von Metternich, Mémoires, documents et écrits, Volume 3, Paris: Plon, 1881, 204-206, 205 f.

iv Metternich to his son Victor, 11 June 1827, in: Aus Metternich's nachgelassenen Papieren, Part II, Volume 2, 335.

v On Viardot's cosmopolitan lifestyle see Figes 2019. On the broader context of female singers as working artists see Rutherford 2006. On the intersection of urban and transnational conditions of vocal practices see Parker and Rutherford, eds 2019.

${ }^{v i}$ Clemens Wenzel Lothar Fürst von Metternich, Tagebuch 18. May 1821, in Aus Metternich's nachgelassenen Papieren, Part II, Volume 1, 440. On the global dimension of the Revolutions of 1820-23 see Späth 2012; Späth 2019.

vii See Mährisch-Ständische Brünner Zeitung, 9. 10.1823.

viii Allgemeine Theaterzeitung, 07.05.1831, 223.

ix Giuseppe Mazzini to Emilie Ashurst Venturi, 21 May 1867, in: Mazzini, Edizione nazionale, 45 ff. Giuseppe Mazzini to Emilie Ashurst Venturi, 21 May 1867, in: Edizione nazionale: Scritti editi ed inediti di Giuseppe Mazzini (Mario Menghini, ed.), vols.1-106 (Imola, 1906-43), vol. 85, 44-47, 45 ff. At the time of writing his original version of Filosofia della musica Mazzini did not know Meyerbeer's Huguenots. For an analysis of Mazzini’s response see Körner 2017c.

${ }^{x}$ In 1838 Il Subalpino featured several poems by Montanelli alongside the Italian translation of an essay by Schlegel, as well as several other articles on the role of Schlegel and Schiller in European literature: Il Subalpino. Giornale di Scienze, Lettere ed Arti II, 2, (1838).

xi La Congiura del Fiesco. Tragedia di Federico Schiller. Traduzione del Cavaliere Andrea Maffei. Milano: Pirola, 1853.
} 